Jurnal Kajian Gender dan Anak

Vol. 02 No. 1 Juni 2018

e-ISSN : 2549-6352, p-ISSN: 2549-6344

Web: jurnal.iain-padangsidimpuan.ac.id/index.php/JurnalGender

\title{
KONSELING INDIVIDU TERHADAP SISWA KORBAN BROKEN HOME (STUDI KASUS DI SMA NEGERI 2 KOTA PADANGSIDIMPUAN)
}

\author{
Riem Malini Pane \\ IAIN Padangsidimpuan \\ riem.malini@gmail.com
}

\begin{abstract}
The problem in this study is how to carry out individual counseling in dealing with broken home victims in SMA Negeri 2 Padangsidimpuan City, what method is used in dealing with broken home victims in SMA Negeri 2 Padangsidimpuan City, why is individual counseling used to deal with broken home victims at SMA Negeri 2 Padangsidimpuan City Based on the above problems, the purpose of this study was to find out the description of the implementation of individual counseling in dealing with broken home victims in SMA Negeri 2 Padangsidimpuan City, to find out the method used in dealing with broken home victims at SMA Negeri 2 Padangsidimpuan City, and to find out the use of individual counseling in dealing with broken home victims in SMA Negeri 2 Padangsidimpuan City. This type of research is qualitative, namely research conducted by observing the surrounding phenomena and analyzing them using scientific logic. The approach used in qualitative research is to use a descriptive qualitative approach, aims to describe systematically and accurately, certain facts and characteristics. Based on this research, it was found that the implementation of individual counseling in dealing with broken home victims in SMA Negeri 2 Padangsidimpuan City not well structured but the $\mathrm{BK}$ teacher himself took the initiative to solve student problems by meeting the homeroom teacher not well structured but the BK teacher himself took the initiative to solve student problems by meeting the homeroom teacher is student acceptance regardless of condition, carrying out assessment of student problems, is empathy and
\end{abstract}

sympathy for students, listening and giving open questions to students, the method used in dealing with broken home victims at SMA Negeri 2 Padangsidimpuan City is directive counseling services provided by the BK teacher to handle the case of students from broken home families in SMA Negeri 2 Padangsidimpuan City is in the form of individual counseling, because it is considered more effective, consideration that student problems are classified as personal problems, also more open students express their problems.

Keywords: individual counseling, students, broken home

\section{Abstrak}

Permasalahan dalam penelitian ini yaitu bagaimana pelaksanaan konseling individu dalam menangani siswa korban broken home di SMA Negeri 2 Kota Padangsidimpuan, apa metode yang digunakan dalam menangani siswa korban broken home di SMA Negeri 2 Kota Padangsidimpuan, mengapa konseling individu yang digunakan untuk menangani siswa korban broken home di SMA Negeri 2 Kota Padangsidimpuan. Berdasarkan masalah di atas maka tujuan penelitian ini adalah untuk mengetahui gambaran pelaksanaan konseling individu dalam menangani siswa korban broken home di SMA Negeri 2 Kota Padangsidimpuan, untuk mengetahui metode yang digunakan dalam menangani siswa korban broken home di SMA Negeri 2 Kota Padangsidimpuan, dan untuk mengetahui penggunaan konseling individu dalam menangani siswa korban broken home di SMA Negeri 2 Kota Padangsidimpuan. Jenis penelitian ini adalah kualitatif yaitu penelitian yang 
dilakukan dengan mengamati fenomena di sekitarnya dan menganalisanya dengan menggunakan logika ilmiah. Pendekatan dalam penelitian kualitatif yang dipakai adalah menggunakan pendekatan kualitatif deskriptif, bertujuan untuk menggambarkan secara sistematis dan akurat, fakta dan karakteristik tertentu. Berdasarkan penelitian ini diperoleh hasil bahwa pelaksanaan konseling individu dalam menangani siswa korban broken home di SMA Negeri 2 Kota Padangsidimpuan belum terstruktur dengan baik namun guru BK sendiri berinisiatif untuk menuntaskan masalah siswa dengan menjumpai wali kelas serta menanyakan perkembangannya, prosedur pelaksanaan konseling individu dengan siswa korban broken home adalah penerimaan siswa bagaimanapun kondisinya, melaksanakan assessment permasalahan siswa, bersifat empati dan simpati terhadap siswa, mendengarkan dan memberikan pertanyaan terbuka kepada siswa, metode yang digunakan dalam menangani siswa korban broken home di SMA Negeri 2 Kota Padangsidimpuan adalah konseling direktif, layanan yang diberikan guru BK untuk menangani kasus siswa dari keluarga broken home di SMA Negeri 2 Kota Padangsidimpuan adalah berupa konseling individu, karena dianggap lebih efektif, dengan pertimbangan bahwa masalah siswa tergolong masalah pribadi, juga siswa lebih terbuka mengungkapkan permasalahannya.

Kata Kunci: Konseling Individu, Siswa, Broken

Home

\section{A. Pendahuluan}

Siswa mempunyai peran penting dalam pembangunan bangsa dan negara. Siswa merupakan generasi penerus yang diharapkan dapat membangun dan berkarya bagi negara. Anak-anak yang terdidik, disiplin, dan berkualitas secara intelektual, mental dan spiritual akan mampu berkompetisi dalam menjalankan roda kehidupan berbangsa dan bernegara, sehingga kelangsungan dan martabat bangsa dapat terjamin. Oleh karenanya, siswa sebagai generasi penerus cita-cita bangsa dan pembangunan nasional, perlu ditingkatkan pembinaan dan pengembangannya serta diarahkan sehingga benar-benar dapat berkembang sebagaimana mestinya yaitu menjadi tumpuan masa depan bangsa dan negara.

Menurut (Tohirin, 2013) Permasalahan yang dialami siswa di sekolah sering kali tidak dapat dihindari, meski dengan pengajaran yang baik sekalipun. Hal ini terlebih lagi disebabkan karena sumber-sumber permasalahan siswa yang banyak terletak di luar sekolah. Dalam kaitan 
ini, permasalahan siswa tidak boleh dibiarkan begitu saja. Apabila misi sekolah adalah menyediakan pelayanan yang luas untuk membantu siswa mencapai tujuan-tujuan perkembangannya dan mengatasi permasalahannya, maka segenap kegiatan dan kemudahan yang diselenggarakan sekolah perlu diarahkan ke sana. Di sinilah dirasakan perlu pelayanan bimbingan dan konseling di samping kegiatan pengajaran. Pelayanan bimbingan dan konseling di sekolah sangat penting dilaksanakan guna membantu siswa mengatasi berbagai masalah yang dihadapinya.

Salah satu wahana dalam menumbuh kembangkan potensi siswa adalah melalui keluarganya. Keluarga memiliki peran yang sentral untuk menunjang keberhasilan belajar siswa. Siswa yang memiliki keluarga yang harmonis, peduli dan bertanggung jawab akan menghantarkannya kepada pintu keberhasilan, dan setidaknya siswa lebih siap untuk menghadapi realitas dunia pendidikannya. Hal yang sebaliknya, apabila keluarga kurang memperhatikan dan anak bebas tanpa pantauan orangtua, maka peluang jenis permasalahan yang dihadapi siswa tidak hanya dari lingkungan belajarnya, namun juga permasalahan yang bersumber dari keluarga.

Guru bimbingan dan konseling mempunyai peran penting dalam membantu siswa menyelesaikan masalah mereka melalui layananlayanan, salah satunya melalui layanan konseling individu. Konseling individu dalam hal ini merupakan layanan yang tepat diberikan pada siswa yang mengalami masalah pribadi, dalam hal ini yaitu siswa yang mempunyai permasalahan dalam keluarganya yang berlatar belakang broken home.

Hasil wawancara yang dilakukan peneliti dengan Guru bimbingan dan konseling Ibu Dewi Narti,S.Pd di SMA Negeri 2 Kota Padangsidimpuan, data informasi yang diperoleh mengenai siswa yang broken home cenderung memiliki kasus yang sangat kompleks yang semuanya 
mengarah kepada perilaku kenakalan yang dilakukan oleh siswa yaitu membolos, berkelahi, merokok, berbohong dengan memalsukan surat ijin, tidak disiplin dalam proses KBM (Kegiatan Belajar Mengajar), sering terlambat masuk kelas/sekolah, pakaian tidak sesuai ketentuan sekolah, dan tidak mengerjakan tugas dari guru.

\section{B. Metodologi}

\section{Jenis Penelitian}

Menurut (Rosady Ruslan, 2004) masalah yang diajukan dalam penelitian ini, jenis penelitian ini adalah penelitian lapangan (field research), yaitu penelitian yang dilakukan di lapangan bertujuan untuk memperoleh informasi dan mendeskripsikan peristiwa, kejadian yang terjadi di lapangan sesuai dengan fakta yang ditemukan di lapangan. Adapun pendekatan yang peneliti gunakan adalah pendekatan kualitatif dengan analisis deskriptif.

Dengan itu dapat disimpulkan bahwa pada dasarnya penelitian ini merupakan kegiatan penelitian untuk mengumpulkan data, menyajikan informasi selanjutnya mendeskripsikan keadaan sebenarnya yang terjadi di lapangan mengenai konseling individu terhadap siswa korban broken home di SMA Negeri 2 Kota Padangsidimpuan dan menarik kesimpulan yang ada di lapangan.

\section{Sumber Data}

Menurut (Salim dan Syahrum, 2007) Sumber data adalah subjek dari mana data dapat diperoleh dan pendapat (Lexy J. Moleong, 2013) Sumber data utama dalam penelitian kualitatif adalah kata - kata, tindakan, dan selebihnya adalah data tambahan seperti dokumen dan lain-lain. Data yang akan dikumpulkan dalam penelitian ini adalah data yang sesuai dengan fokus penelitian. 
Data yang dibutuhkan dalam penelitian ini terdiri dari dua macam sumber, yaitu sebagai berikut:

a. Data Primer

Menurut (Ahmad Nizar Rangkuti, 2014) Data primer adalah proses pengambilan data yang dihimpun langsung oleh peneliti, artinya sumber data yang langsung memberikan data kepada pengumpul data. Dari hal tersebut sumber data primer peneliti dalam mendapatkan informasi dalam penelitian ini adalah Guru bimbingan dan konseling di SMA Negeri 2 Kota Padangsidimpuan yang berperan sebagai pelaksana konseling individu.

b. Data Sekunder

Menurut (Sugiyono, 2013) Adapun data sekunder, merupakan sumber yang tidak langsung memberikan data kepada pengumpul data, misalnya lewat orang lain atau lewat dokumen.

Sumber data sekunder atau data pendukung dalam penelitian ini adalah wali kelas, siswa, dan dokumen yang dianggap relevan dengan masalah yang sedang diteliti.

\section{Instrumen Pengumpulan Data}

a. Wawancara

Menurut (Syukur Kholil, 2006) Jenis wawancara yang digunakan dalam penelitian ini adalah wawancara tidak terstruktur, yaitu wawancara yang bebas di mana peneliti tidak menggunakan pedoman wawancara yang telah tersusun secara sistematis dan lengkap untuk pengumpulan datanya. Wawancara tidak terstruktur merupakan pedoman wawancara yang hanya memuat garis-garis besar yang akan ditanyakan ketika di lapangan. 
Wawancara dilakukan dengan guru bimbingan dan konseling, siswa dan wali kelas untuk memperoleh data tentang pelaksanaan konseling individu dalam menangani siswa broken home yaitu melalui analisis data klien, pensintesisan data guna mengenali kekuatan dan kelemahan klien, diagnosis masalah, prognosis tentang perkembangan masalah, pemecahan masalah sampai pada tindak lanjut dan peninjauan hasil-hasil konseling.

b. Observasi

Dalam penelitian ini penulis mengamati pelaksanaan konseling individu yang dilakukan oleh guru bimbingan dan konseling terhadap siswa yang mengalami broken home. Menurut (Lexy J. Moleong, 2008) Metode observasi yang digunakan dalam penelitian ini adalah model pengamatan terbuka, yaitu pengamatan yang dilakukan secara terbuka diketahui oleh subjek.

c. Dokumentasi

Dokumen merupakan sumber data yang digunakan untuk melengkapi penelitian, baik berupa sumber tertulis, film, gambar (foto), karya-karya momumental, yang semuanya itu memberikan informasi untuk proses penelitian.

Dokumentasi ini dilakukan untuk memperoleh data tentang profil bimbingan konseling, foto-foto kegiatan bimbingan konseling, catatan kegiatan guru bimbingan konseling dari kasus-kasus yang pernah ditangani di sekolah.

\section{Teknik Analisis Data}

Menurut (Sugiyono, 2013) Analisis data adalah proses mencari dan menyusun secara sistematis data yang diperoleh dari hasil wawancara, catatan lapangan, dan dokumentasi, dengan cara mengorganisasikan data ke dalam kategori, menjabarkan kedalam 
unit-unit, melakukan sintesa, menyusun ke dalam pola, memilih nama yang penting dan yang akan dipelajari, dan membuat kesimpulan sehingga mudah dipahami oleh diri sendiri maupun orang lain.

Adapun langkah-langkah yang akan dilaksanakan adalah sebagai berikut:

a. Menelaah seluruh data yang dikumpulkan dari sumber data (Collection Data)

b. Reduksi Data (Reduction Data)

c. Penyajian Data (Display Data)

d. Kesimpulan (Conclusion)

Dengan demikian kesimpulan dalam penelitian kualitatif mungkin dapat menjawab rumusan masalah yang dirumuskan sejak awal, tetapi mungkin juga tidak, karena seperti telah dikemukakan bahwa masalah dan rumusan masalah dalam penelitian kualitatif masih bersifat sementara dan akan berkembang setelah penelitian berada di lapangan.

\section{Teknik Keabsahan Data}

Dalam penelitian kualitatif diperlukan keabsahan data. Adapun teknik keabsahan data yang digunakan dalam penelitian ini adalah menggunakan triangulasi. Triangulasi adalah teknik pemeriksaan keabsahan data yang memanfaatkan sesuatu yang lain di luar data itu untuk keperluan pengecekan atau sebagai perbandingan.

Triangulasi yang dilakukan peneliti dengan cara:

a. Membandingkan data hasil pengamatan dengan hasil wawancara.

b. Membandingkan hasil penelitian dengan fakta di lapangan.

Setelah hasilnya diketahui yang harus dilakukan peneliti adalah membandingkan hasil yang diperoleh berdasarkan hasil penelitian dengan fakta atau nyata yang terjadi di lapangan, untuk mengetahui 
apakah hasil penelitian sudah sesuai secara fakta atau nyata serta meningkatkan derajat keabsahan data peneliti.

\section{HASIL PEMBAHASAN}

\section{Pelaksanaan konseling individu dalam menangani siswa korban} broken home di SMA Negeri 2 Kota Padangsidimpuan

Pelaksanaan layanan konseling individu di SMA Negeri

2 Kota Padangsidimpuan merupakan salah satu bentuk penanganan untuk membantu siswa korban broken home. Layanan konseling individu ini diselenggarakan oleh seorang guru BK terhadap seorang siswa dalam rangka pengentasan masalah pribadi siswa khususnya mengenai masalah keluarga siswa.

Berdasarkan observasi dan hasil wawancara dengan koordinator BK ibu Ostima, S.Pd., bahwa pelaksanaan konseling individu dalam menangani siswa korban broken home di SMA Negeri 2 Kota Padangsidimpuan belum terstruktur dengan baik namun guru BK sendiri berinisiatif untuk menuntaskan masalah siswa dengan menjumpai wali kelas serta menanyakan perkembangannya dengan frekuensi yang terbatas, jadi guru BK sifatnya masih menunggu jika ada laporan dari pihak sekolah mengenai siswa yang memiliki masalah.

Peneliti juga melakukan wawancara dengan koordinator BK ibu Ostima, S.Pd mengenai prosedur pelaksanaan konseling individu dengan siswa korban broken home, beliau mengatakan bahwa:

a. Penerimaan siswa bagaimanapun kondisinya

b. Melaksanakan assessment permasalahan siswa

c. Bersifat empati dan simpati terhadap siswa

d. Mendengarkan dan memberikan pertanyaan terbuka kepada siswa agar siswa dengan leluasa menyampaikan permasalahannya. Sementara metode yang digunakan guru BK terhadap siswa korban 
broken home pendekatan direktif yaitu guru BK lebih aktif dibanding siswa dan menampung semua permasalahan siswa supaya siswa nyaman.

Kemudian peneliti juga melakukan wawancara dengan salah satu siswa korban broken home dan wali kelas tentang pelaksanaan konseling individu yang dilaksanakan di SMA Negeri 2 Kota Padangsidimpuan, siswa ini menyampaikan bahwa dia sangat terbantu dengan adanya konseling individu sehingga masalah yang selama ini dipendam dapat tercurahkan dalam konseling individu terutama masalah keluarga dan wali kelas juga menyampaikan bahwa dengan adanya konseling individu siswa yang memiliki masalah cukup terbantu dengan melihat perubahan perilaku siswa di dalam kelas maupun di lingkungan sekolah dan hubungan sosial dengan teman-temannya.

\section{Metode yang digunakan dalam menangani siswa korban broken home di SMA Negeri 2 Kota Padangsidimpuan}

Menurut hasil wawancara peneliti dengan koordinator BK ibu ostima, S.Pd di SMA Negeri 2 Kota Padangsidimpuan siswa dari keluarga broken home yang ditangani adalah mereka yang menunjukkan adanya pelanggaran aturan, hambatan dalam belajar, sering absen, sering terlambat, merokok, ribut di kelas. Ada empat kasus yang peneliti paparkan tentang permasalahan siswa yang disebabkan oleh permasalahan keluarga broken home yang pernah terjadi dan cara penanganan yang dilakukan guru BK di SMA Negeri 2 kota Padangsidimpuan.

Pertama kasus Z, cara penanganan yang dilakukan guru BK memberi nasehat tentang bagaimana seharusnya sikap Z menghadapi masalah, kalau kita ada masalah seharusnya dicari solusinya jangan malah melampiaskan ke hal-hal yang negatif, itu hanya menambah 
permasalahan baru, $\mathrm{Z}$ juga dinasehati tentang tanggung jawabnya sebagai seorang anak, apalagi Z adalah seorang lelaki, yang kelak memikul tanggung jawab keluarga, menjaga nama baik keluarga.

Penanganan permasalahan Z ini guru BK menggunakan metode/ teori-teori konseling, langkah-langkah konseling juga dilaksanakan. Metode konseling yang digunakan guru BK adalah konseling direktif .

Kedua kasus SR, dalam menangani kasus SR guru BK memberi nasehat tentang masalah pergaulannya kalau cara SR itu tidak benar, bagaimanapun seorang perempuan seharusnya dapat menjaga kesuciannya dan guru BK menyarankan agar SR ini perlahan-lahan menjauhi pacarnya yang non muslim karena takut terjadi kesalahan untuk yang kedua kalinya. Metode konseling yang digunakan guru BK adalah konseling direktif .

Ketiga kasus $\mathrm{T}$, dalam penanganan kasus $\mathrm{T}$ guru BK bekerjasama dengan kepala sekolah, wali kelas, dan ibu T, T yang sudah melanggar peraturan dan melebihi batas ketentuan seharusnya diberi sanksi yaitu dikeluarkan dari sekolah, akan tetapi melihat latar belakang permasalahan yang ada, $\mathrm{T}$ adalah korban dari keluarganya yang broken home, dengan pertimbangan tersebut dan demi kebaikan $\mathrm{T}$, maka pihak sekolah memberikan kesempatan agar bisa tetap bersekolah di SMA Negeri 2 Kota Padangsidimpuan dengan membuat perjanjian untuk tidak mengulangi perbuatannya.

Dalam penanganan kasus T ini guru BK bisa mengacu pada fungsi bimbingan konseling, yaitu fungsi pemeliharaan dan pengembangan. Guru BK perlu menyadari bahwa pelayanan yang diberikan juga mengemban fungsi pemeliharaan dan pengembangan untuk mengoptimalkan potensi dan perkembangan $\mathrm{T}$, baik di sekolah maupun di luar sekolah. Metode konseling yang digunakan guru BK adalah konseling direktif. 
Kasus keempat, dalam penanganan kasus SN maka guru BK bekerjasama dengan agar SN selalu dipantau bagaimana perkembangannya dikarenakan tidak ada kerjasama dari orangtua/wali. Metode konseling yang digunakan oleh guru BK adalah metode konseling direktif

Dari ke empat kasus siswa korban broken home di SMA Negeri 2 Kota Padangsidimpuan menurut peneliti metode penanganan yang dilakukan sebaiknya adalah metode konseling elektrik dengan pendekatan behavior.

\section{Penggunaan konseling individu dalam menangani siswa korban} broken home di SMA Negeri 2 Kota Padangsidimpuan

Berdasarkan hasil wawancara dengan koordinator BK Di SMA Negeri 2 Kota Padangsidimpuan yang bernama ibu Ostima, S.Pd, kegiatan konseling individu berjalan dengan baik, guru BK aktif melakukan pemberian layanan. Layanan konseling individu biasanya dilakukan di ruang BK.

Pada dasarnya guru BK di SMA Negeri 2 Kota Padangsidimpuan tidak memiliki data khusus mengenai keluarga siswa, siswa diketahui berasal dari keluarga broken home pada saat dilakukan wawancara konseling. Pada mulanya guru BK mendapat laporan dari wali kelas siswa yang bersangkutan tentang perilaku yang dilakukan siswa, setelah itu siswa yang bersangkutan dipanggil ke ruang BK untuk diberi teguran dan kemudian dinasehati, siswa juga dimintai keterangan terkait pelanggaran yang dilakukannya, untuk menggali permasalahan siswa lebih dalam guru BK melakukan wawancara, mengajukan beberapa pertanyaan terkait masalah di sekolah dan di luar sekolah termasuk keadaan keluarga, biasanya guru BK akan mengetahui bahwa siswa tersebut dari keluarga broken home. 
Berdasarkan hasil wawancara peneliti dengan guru BK ibu Murni, S.Pd adalah umumnya layanan yang diberikan guru BK untuk menangani kasus siswa dari keluarga broken home di SMA Negeri 2 Kota Padangsidimpuan adalah berupa konseling individu, karena dianggap lebih efektif, dengan pertimbangan bahwa masalah siswa tergolong masalah pribadi, juga siswa lebih terbuka mengungkapkan permasalahannya. Hal yang sama juga disampaikan siswa pada hasil wawancara peneliti bahwa mereka lebih nyaman dan terbuka mengungkapkan masalah mereka ketika dilakukan konseling individu. Konseling dilakukan di ruang BK, dalam konseling biasanya siswa diberi nasehat, motivasi, juga diperkenalkan tentang arti tanggung jawab. Kerjasama yang dilakukan guru BK dalam penanganan kasus biasanya dengan wali kelas, kepala sekolah, dan orangtua (pihak keluarga) siswa.

\section{KESIMPULAN DAN SARAN}

\section{A. Kesimpulan}

Berdasarkan uraian dari hasil penelitian dan pembahasan yang telah dilakukan, maka peneliti dapat menarik kesimpulan bahwa:

1. Prosedur pelaksanaan konseling individu dengan siswa korban broken home adalah penerimaan siswa bagaimanapun kondisinya, melaksanakan assessment permasalahan siswa, bersifat empati dan simpati terhadap siswa, mendengarkan dan memberikan pertanyaan terbuka kepada siswa agar siswa dengan leluasa menyampaikan permasalahannya.

2. Metode yang digunakan guru BK terhadap siswa korban broken home pendekatan direktif yaitu guru BK lebih aktif dibanding siswa dan menampung semua permasalahan siswa supaya siswa nyaman. 
3. Penggunaan konseling individu dianggap lebih efektif, dengan pertimbangan bahwa masalah siswa tergolong masalah pribadi dan siswa lebih terbuka mengungkapkan permasalahannya.

\section{B. Saran}

Berdasarkan hasil penelitian, peneliti menyarankan beberapa hal sebagai berikut:

1. Bagi program studi BKI, adanya kajian yang serius dan mendalam tentang pelaksanaan dan metode konseling individu mengenai kasus broken home.

2. Bagi guru BK, semoga bisa melaksanakan dan memberikan metode konseling individu yang sesuai dalam penanganan siswa yang mengalami keluarga broken home.

3. Saran untuk penelitian selanjutnya, agar bisa mengeksplor lagi mengenai hal-hal terkait kasus broken home, karena di berbagai sekolah masih banyak terkait masalah siswa broken home. 


\section{DAFTAR PUSTAKA}

Ahmad Nizar Rangkuti, Metode Penelitian Pendidikan. Bandung: Citapustaka Media, 2014

Lexy J. Moleong, Metodologi Penelitian Kualitatif. Bandung: PT. Remaja Rosdakarya, 2013

Rosady Ruslan, Metode Penelitian : Public Relation \& komunikasi. Jakarta: RajaGrapindo Persada, 2004

Salim dan Syahrum, Metode Penelitian Kualitatif. Bandung: Citapustaka Media, 2007

Sugiyono, Metode Penelitian Kuantitatif, Kualitatif Dan R\&D. Bandung: Alfabeta, 2013

Syukur Kholil, Metodologi Penelitian Komunikasi. Bandung: Citapustaka Media, 2006

Tohirin, Bimbingan dan Konseling di Sekolah dan Madrasah (Berbasis Integrasi). Jakarta: RajaGrafindo Persada, 2013 
Jurnal Kajian Gender dan Anak

Vol. 02 No. 1 Juni 2018

Pusat Studi Gender dan Anak

IAIN Padangsidimpuan

KESETARAAN DAN KEADILAN GENDER DALAM USAHA TANI PADI

DI DESA TOBING JULU KEC HURISTAK KAB PADANG LAWAS

Risalan Basri Harahap

IAIN Padangsidimpuan

risalanbasriharahap@iain-padangsidimpuan.ac.id 